\title{
PENGARUH BERBAGAI VARIETAS JAGUNG MANIS ( Zea mays saccharata Sturt ) TERHADAP TINGGI TANAMAN, JUMLAH DAUN DAN KANDUNGAN LIGNIN TANAMAN JAGUNG
}

\section{The Effect of Variety of Sweet Corn Varieties (Zea mays saccharata sturt) on High Crop, Number of Leaves and Lignin Contents of Corn Crop}

\author{
Widiati Oktaviani ${ }^{1}$, Lizah Khairani ${ }^{2}$ dan Nyimas Popi Indriani ${ }^{2}$
}

${ }^{1}$ Program Sarjana Ilmu Peternakan, Fakultas Peternakan, Universitas Padjadjaran Kampus Jatinagor, Jl. Raya Bandung-Sumedang KM.21, Jatinangor-Sumedang, Jawa Barat 45363

${ }^{2}$ Departemen Nutrisi Ternak dan Teknologi Ternak Pakan, Fakultas Peternakan, Universitas Padjadjaran. Kampus Jatinangor, Jl. Raya Bandung-Sumedang KM.21, JatinangorSumedang,

Jawa Barat 45363

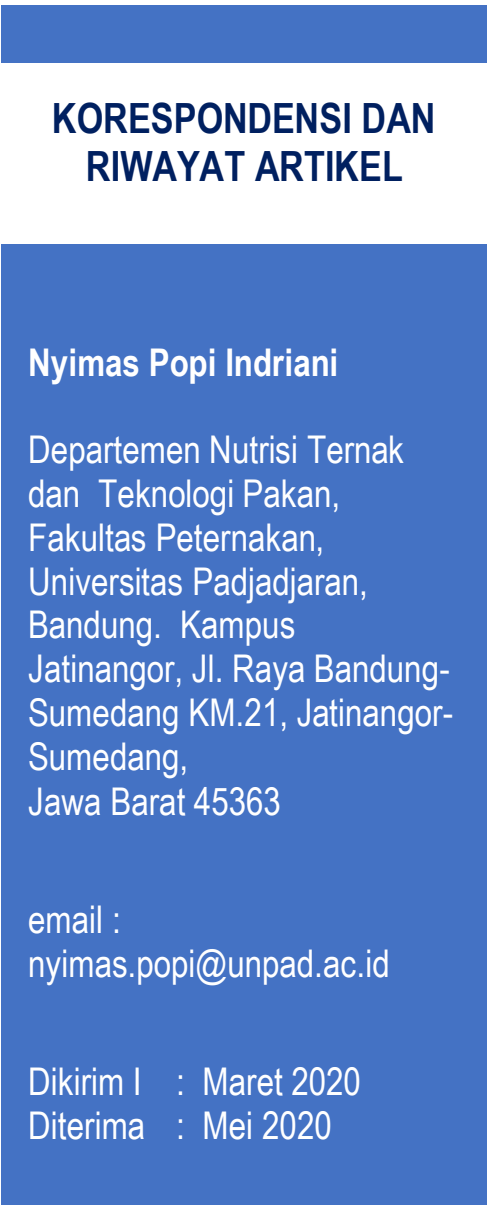

\begin{abstract}
ABSTRAK
Tanaman jagung manis (Zea mays saccharata Sturt) merupakan salah satu jenis pakan hijauan yang merupakan sumber serat kasar bagi ternak ruminansia. Tanaman jagung manis (Zea mays saccharata Sturt) memiliki beberapa varietas yang berbeda. Setiap varietas memiliki keunggulannya masing-masing baik dalam segi produktivitas maupun kandungan nutrisi dan anti nutrisinya. Tujuan dari penelitian ini adalah untuk mengetahui pengaruh berbagai varietas Jagung Manis (Zea mays saccharata Sturt) terhadap tinggi tanaman, jumlah daun dan kandungan lignin tanaman jagung, mengetahui varietas Jagung Manis (Zea mays saccharata Sturt) yang memberikan hasil tertinggi terhadap tinggi tanaman dan jumlah daun, serta untuk mengetahui varietas Jagung Manis (Zea mays saccharata Sturt) yang memberikan hasil terendah terhadap kandungan lignin Tanaman Jagung. Penelitian ini dirancang dengan metode eksperimental menggunakan Rancangan Acak Lengkap (RAL). Terdapat lima jenis perlakuan varietas berbeda tanaman jagung manis, $\mathrm{P} 1=$ Varietas Talenta, $\mathrm{P} 2=$ Varietas Manise, $\mathrm{P} 3=$ Varietas Asia, P4 = Varietas Bonanza, dan P5 = Varietas Paragon dengan 4 kali ulangan. Hasil analisis statistik menunjukkan bahwa perlakuan berbagai varietas jagung manis (Zea mays saccharata Sturt) memberikan pengaruh terhadap tinggi tanaman, jumlah daun, dan kandungan lignin tanaman jagung
\end{abstract} dan menghasilkan tinggi tanaman tertinggi serta jumlah daun terbanyak pada varietas talenta dengan rataan tinggi tanaman jagung manis varietas talenta yaitu $116,78 \mathrm{~cm}$ dan rataan jumlah daun varietas talenta yaitu 11,75 helai sedangkan kandungan 
lignin yang terendah didapatkan pada varietas bonanza yaitu dengan persentase kandungan lignin $10,04 \%$.

Kata kunci : Varietas, jagung manis, tinggi tanaman, jumlah daun, lignin.

\section{ABSTRACT}

Sweet corn (Zea mays saccharata Sturt) was one type of forage feed which is a source of crude fiber for ruminants. Sweet corn crop (Zea mays saccharata Sturt) had several different varieties. Each variety had its own advantages both in terms of productivity and nutritional content and anti-nutrition. The purpose of this study were to determine the effect of various varieties of Sweet Corn (Zea mays saccharata Sturt) on plant height, number of leaves and lignin content of corn crops by knowing which varieties of Sweet Corn (Zea mays saccharata Sturt) gave the highest yield to crop height and the number of leaves, and to find out which varieties of Sweet Corn (Zea mays saccharata Sturt) gave the lowest yield to the lignin content of Corn crops. This study was designed with an experimental method using a Completely Randomized Design (CRD). There were five types of treatment of different varieties of sweet corn crops, $P 1=$ Talent Varieties, $P 2=$ Manise Varieties, $P 3=$ Asian Varieties, $P 4=$ Bonanza Varieties, and P5 = Paragon Varieties with 4 replications. The results of statistical analysis showed that the treatment of various varieties of sweet corn (Zea mays saccharata Sturt) had an influence on plant height, leaf number and lignin content of corn crops and produced the highest crop height and the highest number of leaves on talent varieties with high average sweet corn varieties of talenta varieties which is $116.78 \mathrm{~cm}$ and the average number of leaves of talenta varieties is 11.75 strands while the lowest lignin content is found in bonanza varieties, namely with a percentage of lignin content of $10.04 \%$.

Keywords: Varieties, sweet corn, crop height, number of leaves, lignin.

\section{PENDAHULUAN}

Tanaman jagung mempunyai fungsi multiguna, baik untuk pangan, pakan, industri dan benih. Perbedaan jenis jagung manis dengan jenis jagung lainnya adalah kandungan gula lebih tinggi sehingga memiliki rasa yang lebih manis dan sangat digemari masyarakat. Usaha pengembangan jagung manis di Indonesia mempunyai prospek yang cukup baik. Tanaman jagung manis ditanam oleh petani untuk diambil jagungnya, hasil sampingannya dapat dijadikan sebagai hijauan pakan ternak. Hasil sampingan berupa hijauan tanaman jagung ini akan sangat berguna untuk dijadikan makanan ternak ruminansia. Menurut Mansyur dkk. (2005) bahwa Hasil sampingan tanaman pertanian mempunyai kontribusi yang cukup besar sebagai sumber hijauan pakan. Sistem tanaman pangan yang hasil sampingannya telah banyak digunakan salah satunya adalah jagung. Hasil penelitian Indriani, dkk. (2015) bahwa hijauan tanaman pertanian, salah satunya tanaman jagung dapat dimanfaatkan untuk ternak ruminansia karena kandungan seratnya dan disukai ternak, merupakan bahan pakan penting saat rumput sulit diperoleh, terutama pada musim kemarau.

Faktor genetik dan lingkungan sangat mempengaruhi perkecambahan benih jagung. Jagung manis berbagai varietas memberikan pertumbuhan dan produksi yang beragam. Hal tersebut sejalan dengan pendapat Rochana, dkk. (2016) bahwa pertumbuhan tanaman dipengaruhi oleh dua faktor, yaitu faktor dalam (internal factor) yang merupakan sifat dalam tanaman (benih) dan faktor lingkungan (environmental factors) sifat luar dari tanaman. Selanjutnya menurut Akmalia dan Suharyanto (2017) bahwa adaptasi tanaman terhadap lingkungan, salah satunya ditandai dengan respon fisiologis. Hal ini sangat terkait dengan produktivitas tanaman karena terjadi perubahan mekanisme fisiologis yang akan menjadi kunci fenotipe dan produktivitas yang dihasilkan. 
Umur tanaman di bawah 42 HST (Hari Setelah Tanam), maka pertumbuhan tinggi tanaman dipengaruh oleh faktor genetik dari masing-masing varietas. Sedangkan saat umur jagung 49 HST pertumbuhan tinggi tanaman sudah tidak dipengaruhi oleh genetik karena tanaman jagung sudah memasuki masa generatif (Mahdiannoor dan Istiqomah, 2015). Malai bunga jantan biasanya muncul pada umur 40-50 HST, setelah itu diikuti bunga betina 1-3 hari kemudian (Purwono dan Hanny, 2011). Fase tasseling (berbunga jantan) biasanya berkisar antara 45-52 hari, ditandai oleh adanya cabang terakhir dari bunga jantan sebelum kemunculan bunga betina (rambut tongkol) dimana pada periode ini tinggi tanaman hampir mencapai maksimum dan mulai menyebarkan serbuk sari (pollen). Sesudah koleoptil muncul di atas permukaan tanah, daun jagung mulai terbuka. Setiap daun terdiri atas helaian daun, ligula, dan pelepah daun yang erat melekat pada batang. Jumlah daun sama dengan jumlah buku batang. Jumlah daun umumnya berkisar antara 10 -18 helai, rata- rata munculnya daun yang terbuka sempurna adalah 3-4 hari setiap daun. Tanaman jagung di daerah tropis mempunyai jumlah daun relatif banyak dibanding di daerah beriklim sedang (Subekti dkk, 2007). Menurut Kuruseng, dkk. (2008) varietas berpengaruh pada jumlah daun tanaman jagung. Pertambahan jumlah daun maksimal pada umur 6 MST (Minggu Setelah Tanam), kemudian terlihat tetap bahkan menurun. Hal ini disebabkan karena terjadi proses penuaan tanaman yang ditandai dengan mulai mengeringnya daun bagian bawah tanaman (Setyowati dan Ning, 2013)

Setiap varietas jagung manis memiliki karakteristik yang berbeda-beda termasuk jumlah daun yang dihasilkan. Jumlah daun yang dihasilkan tersebut akan berpengaruh terhadap banyaknya hijauan pakan yang dihasilkan. Pertumbuhan daun pada tanaman jagung manis dapat dijadikan sebagai indikator dari pertumbuhan tanaman tersebut, yang secara logika dapat dikatakan bahwa semakin banyak daun yang tumbuh maka semakin besar pula peluang tanaman melakukan proses fotosintesis. Varietas Bonanza mampu beradaptasi dengan lingkungan jika dibandingkan varietas Jago F1. Selain itu adaptasi yang baik terhadap lingkungan akan berdampak pada produksi atau hasil tanaman itu sendiri. Tanaman jagung manis varietas Bonanza F1 memiliki tinggi tanaman dan jumlah daun yaitu 195, 29 $\mathrm{cm}$ dan 12 helai dibandingkan dengan varietas Jago F1 yaitu 183, $23 \mathrm{~cm}$ dan 11 helai (Mahdiannoor dan Istiqomah, 2015).

Jagung manis merupakan hijauan pakan sebagai sumber serat kasar. Pada bahan pakan asal tanaman faktor penghambat didominasi oleh kelompok senyawa fenolik polimer seperti lignin yang terdapat di dalam dinding sel (Sirappa, 2003). Selulosa dan lignin sebagai penyusun dinding sel akan meningkat jumlahnya seiring peningkatan jumlah floemnya. Selulosa dan lignin merupakan penentu serat (Mudyantini, 2008). Semakin tinggi tanaman, jumlah daun pada tanaman jagung akan semakin banyak dan dinding sel tanaman akan semakin luas, sehingga tinggi tanaman dan jumlah daun akan berpengaruh terhadap kandungan serat kasar dan lignin tanaman jagung manis. Menurut Bogdan (1997) serat kasar merupakan dinding sel tanaman terdiri dari selulosa dan hemiselulosa yang dilapisi lignin dan silika. Semakin keras dan kuat dinding sel tanaman sebagai penopang tanaman maka kandungan serat termasuk lignin akan semakin tinggi begitupun sebaliknya.

Beberapa variteas tanaman jagung manis memiliki tinggi tanaman dengan umur panen yang berbeda. Keputusan Mentri Pertanian Nomor 3634/Kpts/SR. 120/10/2009 varietas Talenta memiliki tinggi tanaman 170-200 cm dengan umur panen 70-76 HST, tinggi tanaman varietas Bonanza $220-250 \mathrm{~cm}$ umur panen 82-84 HST, tinggi tanaman Paragon 185,2-215,7 cm umur panen 70-75 HST sedangkan untuk varietas Asia dan Manise belum banyak ditanam di Indonesia. Berdasarkan hal tersebut peneliti tertarik untuk menggunakan varietas Manise dan Asia dalam penelitian ini. Umur panen varietas manise yaitu $80 \mathrm{HST}$ dan varietas Asia 65-67 HST. 
Varietas jagung manis terbaik juga didapatkan pada varietas Bonanza, kemudian Manise dan terendah varietas Pertiwi terhadap potensi tumbuh dan keserempakan tumbuh. Potensi tumbuh merupakan persentase munculnya kecambah yang dihitung berdasarkan jumlah benih yang tumbuh pada pengamatan hari ke 7 terhadap benih yang diuji. Data persentase potensi tumbuh pada varietas Bonanza yaitu 94,33\%, varietas Manise 88,67\% dan varietas Pertiwi 46,67\% (Syafrudin, 2015). Potensi pertumbuhan akan berpengaruh terhadap perbedaan tinggi tanaman dan jumlah daun setiap varietas tanaman jagung manis, semakin besar potensi tumbuh tanaman maka semakin besar potensi tanaman untuk dapat tumbuh dan berkembang dengan baik.

Tujuan dari penelitian ini adalah untuk mengetahui pengaruh berbagai varietas Jagung Manis (Zea mays saccharata Sturt ) terhadap tinggi tanaman, jumlah daun dan kandungan lignin tanaman jagung. Kedua adalah mengetahui varietas Jagung Manis (Zea mays saccharata Sturt) yang memberikan hasil tertinggi terhadap tinggi tanaman dan jumlah daun, serta ketiga adalah untuk mengetahui varietas Jagung Manis (Zea mays saccharata Sturt) yang memberikan hasil terendah terhadap kandungan lignin Tanaman Jagung.

\section{METODE PENELITIAN}

\section{Objek dan Metode}

Penelitian dilakukan di Lahan Percobaan Universitas Padjadjaran, Laboratorium Tanaman Makanan Ternak dan Laboratorium Nutrisi Ternak dan Bahan Kimia Pakan Ternak Fakultas Peternakan Universitas Padjadjaran pada Bulan Maret sampai Juni 2018. Penelitian dilakukan dengan metode eksperimental, menggunakan rancangan lingkungan yaitu Rancangan Acak Lengkap (RAL) dengan lima perlakuan yaitu dengan lima varietas berbeda yaitu : $\mathrm{P} 1=$ Varietas Talenta; $\mathrm{P} 2=$ Varietas Manise; $\mathrm{P} 3=$ Varietas Asia 86; $\mathrm{P} 4=$ Varietas Bonanza; $\mathrm{P} 5=$ Varietas Paragon.

\section{Peubah yang diamati}

Peubah yang diamati dalam penelitian ini adalah Tinggi Tanaman Jagung $(\mathrm{cm})$; Jumlah daun (helai) dan Kandungan Lignin Tanaman (\%) . Untuk mengetahui perbedaan antar perlakuan pada jumlah daun, tinggi tanaman dan kandungan lignin setiap varietas dilakukan pengujian menggunakan Kontras Orthogonal, dengan koefisien pembanding.

Lahan yang ditanam diukur dengan ukuran $15,5 \mathrm{~m} \times 14 \mathrm{~m}$. Kemudian dibuat petak sebanyak 20 buah dengan ukuran $3 \mathrm{~m} \times$ $2 \mathrm{~m}$ dengan jarak antar petak $50 \mathrm{~cm}$. Setiap petak akan dibuat lubang sebanyak 32 lubang dengan jarak antar baris tanaman $70 \mathrm{~cm}$ dan jarak dalam baris tanaman $25 \mathrm{~cm}$. Benih ditanam sebanyak dua biji setiap lubang, setelah satu minggu menjadi satu tanaman setiap lubang. Penyulaman yaitu penanaman kembali pada lubang yang tanamannya tidak tumbuh dan mati. Penyulaman tanaman dilakukan pada 1 MST. Pemupukan dilakukan sebanyak 2 kali. Pemupukan pertama dilakukan pada saat penanaman benih menggunakan pupuk kandang. Pemupukan yang kedua dilakukan pada saat umur tanaman 1 bulan setelah ditanam, pupuk yang digunakan yaitu pupuk NPK 15 : $15: 15$ sebanyak 5,25 gram perlubang tanam. Penyiraman dilakukan tergantung pada cuaca dan kondisi tanah, bila tanah kering dan tidak hujan maka dilakukan penyiraman. Penyiangan dilakukan seminggu sekali dengan cara mencabut gulma yang tumbuh di sekitar tanaman. Pengukuran tinggi tanaman jagung manis dilakukan pada saat tanaman jagung saat berbunga atau telah memasuki awal fase generatif yaitu pada umur 49 HST (Hari Setelah Tanam). Pengukuran dilakukan dengan cara mengukur tanaman jagung dari pangkal batang bawah pada tanah hingga ujung pucuk tanaman tertinggi. Perhitungan jumlah daun tanaman jagung manis dilakukan pada saat tanaman jagung berbunga atau telah memasuki awal fase generatif yaitu pada umur 49 HST. Perhitungan dilakukan dengan cara menghitung jumlah daun pada setiap buku tanaman jagung. Pemanenan dilakukan pada 
saat tanaman berumur 85 HST. Tanaman kemudian dipisahkan perbagian tanaman seperti daun, batang, malai, akar, dan tajuk. Batang dan daun kemudian dicacah menggunakan pisau dan gunting dengan ukuran $\pm 2 \mathrm{~cm}$. Sampel dimasukan ke dalam map dan dikeringkan menggunakan oven dengan suhu $60-70^{\circ} \mathrm{C}$ selama 2 hari. Tanaman jagung yang telah kering kemudian dihaluskan atau dijadikan tepung, kemudian dilakukan analisis kandungan lignin tanaman jagung melalui analisis fraksi serat metode Van Soest (Van Soest, 1967) yang dilakukan di Laboratorium Nutrisi dan Makanan Ternak Ruminansia.Penentuan kandungan lignin merupakan lanjutan dari perhitungan kandungan ADF (Acid Detergent Fiber).

\section{HASIL DAN PEMBAHASAN}

\section{Tinggi Tanaman Jagung Manis}

Hasil sidik ragam ANOVA untuk tinggi tanaman berbagai varietas jagung manis menunjukan bahwa perlakuan berbagai varietas memberikan pengaruh nyata terhadap tinggi tanaman jagung, dengan hasil yang berbeda nyata tersebut kemudian perhitungan dilanjutkan dengan kontras orthogonal untuk mengetahui pengaruh setiap varietas terhadap varietas lainnya. Signifikasi hasil analisis kontras orthogonal dapat dilihat dalam Tabel 1. kecuali Varietas Manise hanya berbeda nyata dengan Varietas Talenta sedangkan dengan Varietas Asia 86, Bonanza dan Paragon tidak berbeda nyata. Perbedaan tinggi tanaman pada berbagai varietas tanaman jagung manis terjadi karena setiap varietas memiliki genetik dan kemampuan daya adaptasi terhadap lingkungan yang berbeda. Hal ini sesuai dengan pernyataan bahwa setiap varietas memiliki perbedaan genetik yang dapat mempengaruhi pertumbuhan, dan hasil serta kemampuan adaptasi suatu varietas berbeda-beda. Varietas terdiri dari beberapa genotipe yang berbeda dimana masingmasing genotipe mempunyai kemampuan menyesuaikan diri terhadap lingkungan yang berbeda pula. Varietas unggul dapat tercermin pada sifat pembawaannya yang dapat menghasilkan buah yang berproduksi tinggi, respons terhadap pemupukan dan resisten terhadap hama dan penyakit. Jenis varietas yang sesuai dengan keadaan lingkungan diharapkan tumbuh dengan baik dan memberikan hasil yang tinggi (Prajnanta, 2004; Tanuwiria dkk., 2007). Untuk mencapai produksi yang tinggi ditentukan oleh potensi varietas unggul. Potensi varietas unggul di lapangan masih dipengaruhi oleh interaksi antara faktor genetik (varietas) dengan pengelolaan kondisi lingkungan. Bila pengelolaan lingkungan tumbuh tidak dilakukan dengan baik, potensi produksi yang tinggi dari varietas unggul tersebut tidak

Tabel 1. Signifikasi Hasil Analisis Kontras Orthogonal Pengaruh Perlakuan Terhadap Tinggi Tanaman Berbagai Varietas Tanaman Jagung Manis

\begin{tabular}{lccc}
\hline & Kontras & Nilai Rataan $(\%)$ & Signifikasi $(0,05)$ \\
\hline K1 & P1 vs P2; P3; P4; P5 & 116,78 vs 88,$71 ; 100 ; 66,43 ; 94,08$ & $\mathrm{~s}$ \\
K2 & P2 vs P3; P4; P5 & 88,71 vs $100 ; 66,43 ; 94,08$ & $\mathrm{~ns}$ \\
K3 & P3 vs P4; P5 & 100 vs 66,43; 94,08 & $\mathrm{s}$ \\
K4 & P4 vs P5 & 66,43 vs 94,08 & $\mathrm{~s}$ \\
\hline
\end{tabular}

Keterangan : P1 = Varietas Talenta, P2 = Varietas Manise, P3 = Varietas Asia 86, P4 = Varietas Bonanza P5 = Varietas Paragon

Berdasarkan hasil kontras orthogonal menunjukan bahwa tinggi tanaman antar varietas jagung manis yang ditanaman pada penelitian berbeda nyata atau signifikan dapat tercapai (Adisarwanto, 2006).

Hasil uji sidik ragam menunjukkan bahwa varietas berpengaruh nyata terhadap tinggi tanaman (umur 49 HST). Perbedaan 
respon yang ditunjukkan pada tinggi tanaman jagung manis akibat perbedaan varietas, diduga disebabkan karena adanya perbedaan sifat genetik dari kelima varietas yang diteliti Perbedaan sifat genetik ini menyebabkan terjadinya perbedaan tanggap kelima varietas tersebut terhadap berbagai kondisi lingkungan, sehingga aktivitas pertumbuhan yang ditunjukkan berbeda. Hal ini sesuai dengan pernyataan Bahri (2017) bahwa penampilan tanaman dikendalikan oleh sifat genetik di bawah pengaruh faktor-faktor lingkungan, kendali genetik pada penampilan tanaman diekspresikan melalui proses biokimia dan fisiologis. Perbedaan susunan genetik merupakan salah satu faktor penyebab keragaman penampilan tanaman. Keragaman penampilan tanaman akibat perbedaan susuanan genetik selalu mungkin terjadi sekalipun bahan tanaman yang digunakan berasal dari jenis tanaman yang sama. Adaptasi merupakan proses individu, populasi atau spesies dalam beberapa hal berubah fungsi atau bentuk jika lebih baik pada lingkungan baru yang diterimanya maka akan baik pertumbuhan dan perkembangan tanamannya sehingga akan berpengaruh pada fase generatif (produksi).

\section{Jumlah Daun Tanaman Jagung Manis}

Hasil sidik ragam ANOVA dari jumlah daun berbagai varietas jagung manis menunjukan bahwa perlakuan berbagai varietas memberikan pengaruh nyata terhadap jumlah daun tanaman jagung, dengan hasil yang berbeda nyata tersebut kemudian perhitungan dilanjutkan dengan kontras orthogonal untuk mengetahui pengaruh setiap varietas terhadap varietas lainnya. Signifikasi hasil analisis kontras orthogonal dapat dilihat dalam Tabel 2.

Signifikasi hasil analisis kontras orthogonal dapat dilihat dalam Tabel 2. Hasil kontras orthogonal menunjukan bahwa jumlah daun antar varietas jagung manis yang ditanam pada penelitian yang berbeda nyata hanya Varietas Talenta dengan Varietas Manise, Asia 86, Bonanza dan Paragon.
Sedangkan antar varietas Manise, Asia 86, Bonanza dan Paragon tidak berbeda nyata.

Verietas Bonanza mampu beradaptasi dengan lingkungan jika dibandingkan varietas Jago F1 dan Manise. Selain itu adaptasi yang baik terhadap lingkungan akan berdampak pada produksi atau hasil tanaman itu sendiri (Mahdiannoor dan Istiqomah, 2015). Varietas Manise memiliki Jumlah daun yang lebih banyak yaitu 12 helai dibandingkan Varietas Bonanza yang hanya memiliki nilai rata- rata jumlah daun yaitu 10 helai (Surtinah, 2016). Sedangkan berdasarkan hasil penelitian ini Varietas Bonanza dan Manise memiliki jumlah daun yang sama. Adanya perbedaan hasil penelitian dengan pernyataan Mahdiannoor dan Istiqomah (2015) dapat disebabkan karena perbedaan kondisi lingkungan penanaman. Hal ini sesuai dengan pernyataan bahwa varietas berperan penting dalam produksi tanaman, karena untuk mencapai hasil yang tinggi sangat ditentukan oleh potensi genetiknya. Potensi hasil di lapangan dipengaruhi oleh interaksi antara faktor genetik dengan pengelolaan kondisi lingkungan. Bila pengelolaan lingkungan tumbuh tidak dilakukan dengan baik, potensi hasil yang tinggi dari varietas unggul tersebut tidak dapat tercapai (Adisarwanto 2006). Perbedaan dan persamaan pada masingmasing sifat kualitatif tersebut ditentukan oleh masing-masing gen dengan faktor lingkungan yang sangat berpengaruh. Berdasarkan fenomena yang ada, dapat disimpulkan bahwa timbulnya karakter yang sama antar varietas kemungkinan disebabkan oleh adanya gen penyusun fenotip yang sama dan dipengaruhi oleh lingkungan sehingga memunculkan fenotip yang relatif sama. Begitu pula dengan timbulnya perbedaan karakter antar varietas kemungkinan disebabkan oleh adanya pengaruh gen yang berbeda (Mustofa, dkk., 2013).

Menurut Subandi (1990) keberhasilan peningkatan produksi sangat tergantung kepada kemampuan penyediaan dan penerapan inovasi teknologi yaitu meliputi varietas unggul baru berdaya hasil dan berkualitas tinggi, penyediaan benih bermutu 
Tabel 2. Signifikasi Hasil Analisis Kontras Orthogonal Pengaruh Perlakuan terhadap Jumlah Daun Berbagai Varietas Tanaman Jagung Manis

\begin{tabular}{cccc}
\hline & Kontras & Nilai Rataan $(\%)$ & Signifikasi $(0,05)$ \\
\hline K1 & P1 vs P2; P3; P4; P5 & 12 vs $10 ; 9 ; 10 ; 10$ & $\mathrm{~s}$ \\
K2 & P2 vs P3; P4; P5 & 10 vs $9 ; 10 ; 10$ & $\mathrm{~ns}$ \\
K3 & P3 vs P4; P5 & 9 vs $10 ; 10$ & $\mathrm{~ns}$ \\
K4 & P4 vs P5 & 10 vs 10 & $\mathrm{~ns}$ \\
\hline
\end{tabular}

serta teknologi budidaya yang tepat. Noorhadi dan Sudadi (2003) menyatakan bahwa selain faktor genetik, faktor lingkungan terutama kelembaban dan suhu di sekitar tanaman sangat mempengaruhi pertumbuhan dan hasil tanaman. Curah hujan merupakan suatu unsur iklim yang dapat berpengaruh terhadap proses pertumbuhan tanaman hal ini dikarenakan curah hujan dapat mempengaruhi suhu dan kelembaban lingkungan penanaman. Berdasarkan data curah hujan yang diperoleh dari Stasiun Hujan No 200 C di Kecamatan Jatinangor, curah hujan rata-rata pada empat bulan penanaman yaitu $128,075 \mathrm{~mm} / \mathrm{bulan}$. Curah hujan tersebut sudah cukup baik untuk menunjang pertumbuhan tanaman jagung sesuai dengan pernyataan dari Badan Penelitian dan Pengembangan Pertanian (2008) tanaman jagung membutuhkan air dengan curah hujan sekitar 100-140 $\mathrm{mm} / \mathrm{bulan}$.

Secara umum jagung mempunyai pola pertumbuhan yang sama, namun interval waktu antar tahap pertumbuhan dan jumlah daun yang berkembang dapat berbeda (Subekti dkk, 2007). Berdasarkan deskripsi umur panen optimal setiap varietas tanaman jagung manis berbeda hal ini menunjukan interval antar fase pertumbuhan tanaman jagung manis setiap varietas juga berbeda dengan demikian waktu perhitungan jumlah daun serempak yaitu pada umur tanaman 49 HST setiap varietas yang dihitung jumlah daunnya berada pada fase pertumbuhan yang berbeda yang menyebabkan adanya perbedaan jumlah daun. Menurut penelitian yang dilakukan Panalosa, dkk., (2015) bahwa fase pengembangan pertumbuhan rata-rata jumlah daun yang terjadi antara perlakuan sedikit berbeda antara varietas dan fase pematangan jumlah daun terlihat sangat berbeda nyata.

\section{Kandungan Lignin Tanaman Jagung Manis}

Hasil sidik ragam ANOVA kandungan lignin berbagai varietas jagung manis menunjukan bahwa perlakuan berbagai varietas memberikan pengaruh nyata terhadap kandungan lignin tanaman jagung, dengan hasil yang berbeda nyata tersebut kemudian perhitungan dilanjutkan dengan kontras orthogonal untuk mengetahui pengaruh setiap varietas terhadap varietas lainnya. Signifikasi hasil analisis kontras orthogonal dapat dilihat dalam Tabel 3.

Berdasarkan hasil penelitian dan analisis data yang telah dilakukan dapat disimpulkan bahwa setiap varietas tanaman jagung manis memiliki persentase kandungan lignin yang berbeda. Hasil kontras orthogonal menunjukan bahwa kandungan lignin antar varietas jagung manis yang ditanaman pada penelitian berbeda nyata atau signifikan kecuali, Varietas Manise hanya berbeda nyata dengan Varietas Talenta. Varietas Asia 86 hanya berbeda nyata dengan Varietas Manise dan Talenta sedangkan dengan Varietas Bonanza dan Paragon tidak berbeda nyata. Perbedaan kandungan lignin pada berbagai varietas tanaman jagung manis terjadi karena setiap varietas memiliki genetik dan kemampuan daya produksi yang berdeda. Hal ini sesuai dengan pernyataan bahwa setiap varietas tanaman yang berbeda menunjukkan pertumbuhan dan hasil yang berbeda walaupun ditanam pada kondisi lingkungan yang sama (Harjadi 1991). Kemampuan pertumbuhan yang berbeda setiap varietas 
akan berpengaruh terhadap kandungan lignin tanaman tersebut. Selulosa dan lignin sebagai penyusun dinding sel akan meningkat jumlahnya seiring peningkatan jumlah floemnya, selulosa dan lignin merupakan
Mutaqin dkk., 2019). Organ tanaman yang mengandung konsentrasi tinggi dari jaringanjaringan ini, seperti batang, kurang dapat dicerna dibandingkan dengan yang mengandung konsentrasi lebih rendah.

Tabel 3. Signifikasi Hasil Analisis Kontras Orthogonal Pengaruh Perlakuan terhadap Kandungan Lignin Berbagai Varietas Tanaman Jagung Manis

\begin{tabular}{cccc}
\hline & Kontras & Nilai Rataan $(\%)$ & Signifikasi $(0,05)$ \\
\hline K1 & P1 vs P2; P3; P4; P5 & 12,55 vs 11,$36 ; 11,08 ; 10,04 ; 11,61$ & $\mathrm{~s}$ \\
K2 & P2 vs P3; P4; P5 & 11,36 vs 11,08; 10,04; 11,61 & ns \\
K3 & P3 vs P4; P5 & 11,08 vs 10,04; 11,61 & ns \\
K4 & P4 vs P5 & 10,04 vs 11,61 & $\mathrm{~s}$ \\
\hline
\end{tabular}

penentu serat (Tanuwiria, 2004, 2007a,b; Mudyantini, 2008).

Berdasarkan hasil penelitian yang didapatkan, kandungan lignin pada berbagai varietas tanaman jagung manis memiliki kandungan lignin yang berbeda hal ini diduga karena setiap varietas memiliki genetik yang berbeda dan kemampuan pertumbuhan dan perkembangan yang tidak sama sehingga memiliki umur panen optimal yang juga berbeda. Umur panen dapat mempengaruhi kandungan lignin pada setiap varietas jagung manis, semakin bertambah umur tanaman jumlah floem pada tanaman akan bertambah. Hal ini sesuai dengan pernyataan Moore dan Jung (2001) dan Adawiah dkk. (2007) bahwa lignin disimpan di dinding sel tanaman sebagai bagian dari proses pematangan sel. Ada sejumlah faktor terkait tanaman yang mempengaruhi lignifikasi pada tanaman individu dan komunitas tanaman. Lignifikasi berada di bawah kendali genetik dan ada perbedaan besar dalam konsentrasi dan komposisi lignin diantara spesies dan bahkan tipe gen dalam spesies. Perbedaan genetik dalam lignifikasi pertama kali diekspresikan pada tingkat sel dan dipengaruhi oleh aktivitas biokimia dan fisiologis sel (Mushawwir, 2015). Saat sel berdiferensiasi, perbedaan lignifikasi terjadi tergantung pada jaringan dan organ yang dikembangkan. Lignifikasi cenderung paling kuat pada jaringan struktural seperti xilem dan sklerenkhyma (Pangestu dkk., 2003;
Proporsi relatif dari jaringan dan organ yang lignifikasi biasanya meningkat ketika tanaman matang sehingga seringkali ada hubungan negatif antara kecernaan dan kematangan. Semua proses instalasi ini merespons faktor lingkungan yang dapat memengaruhi tingkat dan dampak lignifikasi. Suhu, kelembaban tanah, cahaya, dan kesuburan tanah dapat memiliki efek pada lignifikasi.

Menurut Cahya (2018) panen merupakan bagian akhir dari proses budidaya tanaman jagung, umur panen adalah salah satu faktor yang menentukan kualitas jagung manis. Berdasarkan deskripsi setiap varietas tanaman jagung manis dalam keputusan Mentri Pertanian Nomor 3634/Kpts/SR.120/ 10/2009 varietas talenta memiliki umur panen 70-76 HST (hari setelah tanam), varietas paragon memiliki umur panen $70-75$ HST, varietas asia memiliki umur panen 6567 HST, varietas manise memiliki umur panen 60 HST, dan varietas bonanza memiliki umur panen optimal yang paling lama yaitu 82-84 HST. Hasil penelitian varietas bonanza memiliki persentase kandungan lignin terendah dibandingkan varietas yang lain karena umur panen saat penelitian mendekati umur panen berdasarkan deskripsi varietas bonanza. Umur tanaman sangat berpengaruh terhadap berat segar dan berat kering tanaman yang merupakan produksi hijauan dari tanaman jagung. Menurut Indriani, dkk. (2018), umur 
tanaman lebih muda (mendekati umur panen yang seharusnya yang berdasarkan deskripsi pada varietas) akan menurunkan kandungan serat kasar dan biomassa tanaman dan meningkatkan kadar protein kasar hijauan tanaman (batang dan daun),

Perbedaan hasil penelitian dengan data pada deskripsi terjadi karena pada penelitian proses pemanenan semua varietas dilakukan dengan waktu serempak yaitu 85 HST. Hal ini sesuai dengan pernyataan Bogdan (1997) Dan Susilawati et al. (2019) serat kasar merupakan dinding sel tanaman terdiri dari selulosa dan hemiselulosa yang dilapisi lignin dan silika. Semakin keras dan kuat dinding sel tanaman sebagai penopang tanaman maka kandungan serat termasuk lignin akan semakin tinggi begitupun sebaliknya. Semakin tua umur semakin tinggi kadar serat kasar yang ditunjukkan oleh dinding sel tanaman yang semakin keras dan kuat sebagai penopang tanaman. Crowder dan Chedda (1982) mengatakan kadar protein suatu tanaman menurun sesuai dengan meningkatnya umur tanaman, sedangkan kadar serat sebaliknya menjadi meningkat.

Berdasarkan deskripsi umur panen optimal setiap varietas tanaman jagung manis berbeda hal ini menunjukan interval antar fase pertumbuhan tanaman jagung manis setiap varietas juga berbeda dengan demikian dengan waktu pemanenan serempak yaitu pada umur tanaman 85 HST setiap varietas yang dipanen berada pada fase pertumbuhan yang berbeda yang menyebabkan perbedaan persentase kandungan ligninnya. Umur panen merupakan aspek yang erat hubungannya dengan fase pertumbuhan tanaman yang mencerminkan tingkat kematangan fisiologis tanaman dan memiliki relevansi yang kuat dengan produksi dan kandungan yang ada dalam tanaman. Menurut Savitri, dkk., (2012) peningkatan produksi serat disebabkan karena terjadinya proses lignifikasi yang semakin tinggi seiring bertambahnya umur sehingga komponen serat akan meningkat.

\section{KESIMPULAN}

Berbagai varietas jagung manis (Zea mays saccharata Sturt) memberikan pengaruh terhadap tinggi tanaman, jumlah daun, dan kandungan lignin tanaman jagung. Perlakuan berbagai varietas jagung manis (Zea mays saccharata Sturt) menghasilkan tinggi tanaman tertinggi dan jumlah daun terbanyak pada varietas talenta dengan rataan tinggi tanaman jagung manis varietas talenta yaitu $116,78 \mathrm{~cm}$ dan rataan jumlah daun varietas talenta yaitu 11,75 helai. Perlakuan berbagai varietas jagung manis (Zea mays saccharata Sturt) menghasilkan kandungan lignin yang terendah didapatkan pada varietas bonanza yaitu dengan persentase kandungan lignin $10,04 \%$.

\section{DAFTAR PUSTAKA}

Adawiah, A., T. Sutardi, T. Toharmat, dan W. Manalu, N. Ramli, U.H. Tanuwiria. 2007. Respons terhadap suplementasi sabun mineral dan mineral organik serta kacang kedelai sangrai pada indikator fermentabilitas ransum dalam rumen domba. Media Peternakan 30:162-169.

Adisarwanto, T. 2006. Budidaya Kedelai dengan Pemupukan yang Efektif dan Pengoptimalan Peran Bintil Akar. Penebar Swadaya, Jakarta.

Akmalia, H.A. dan E. Suharyanto. 2017. Respon fisiologis dan produktivitas Jagung (Zea mays L.) 'Sweet Boy-02' pada perbedaan intensitas cahaya dan penyiraman. J. Tekno Sains. 6:59-138.

Badan Penelitian dan Pengembangan Pertanian. 2008. Teknologi Budidaya Jagung. Balai Besar Pengkajian dan Pengembangan Teknologi Pertanian. Bogor.

Bahri, S. 2017. Respon pertumbuhan dan hasil tiga varietas kedelai (Glycine max, L.) terhadap cekaman kekeringan. J. Penelitian. 4:1-14.

Bogdan AV, 1977. Nutritive Value. Tropical Pasture and Fodder Plans. Longman Inc., London and New York.14-18. 
Cahya, J.E. dan N. Herlina. 2018. Uji potensi enam varietas jagung manis (Zea mays saccharata Sturt) di dataran rendah Kabupaten Pamekasan. J. Produksi Tanaman. 6:92-100.

Crowder L and H.R. Chedda, 1982. Tropical Grassland Husbandry. $1^{\text {st }}$ edition. Longman, New York, London. 308370.

Harjadi, M. M. S. S, 1991. Pengantar Angronomi. Gramedia Pustaka Utama. Jakarta.

Indriani N.P., Y. Yuwariah, A. Rochana and H. Djuned. 2015. Effect of intercropping between corn (Zea mays) and peanut (Arachis hypogaea) with Arbuscular Mycorrhizal Fungi (AMF) on the yield and forarges mineral content. Pakistan J. of Nutrition. 14: 362-365.

Indriani, N. P, Yuwariah, Y, Nuraini, A, dan Ruswandi, D. 2018. Nutrient content of various Padjadjaran Hybrid maize as feed forage at Arjasari Village Bandung. Asian J. of Crop Science. 10:121-126.

Kuruseng, H. dan M.A.Kuruseng. 2008. Pertumbuhan dan produksi berbagai varietas tanaman jagung pada dua dosis pupuk urea. J. Agrisistem 4:26-36.

Mahdiannoor dan N. Istiqomah. 2015. Pertumbuhan hasil dua varietas jagung hibrida sebagai tanaman sela di bawah tegakan karet. Ziraa'ah. 40:46-53.

Mansyur, N. P. Indriani dan I.Susilawati. 2005. Peranan leguminosa tanaman penutup pada sistem pertanian jagung untuk penyediaan hijauan pakan. Seminar Nasional Teknologi Peternakan dan Veteriner. Bogor. 879885

Moore. K. J and H. J. G. Jung. 2001. Lignin and fiber digestion. J. of Range Management. 54: 420-430.

Mudyantini, W. 2008. Pertumbuhan, kandungan selulosa, dan lignin pada rami (Boehmeria nivea L. Gaudich) dengan pemberian asam giberellat $\left(\mathrm{GA}_{3}\right)$. Biodiversitas. 9:269-274.
Mushawwir, A. 2015. Biokimi Nutrisi. Widya Padjadjaran, Bandung.

Mustofa, I. M. Budiarsa, dan G.B.N. Samdas. 2013. Variasi genetik jagung (Zea mays L.) berdasarkan karakter fenotipik tongkol jagung yang dibudidaya di Desa Jono Oge. E-Jipbiol. 1:33-41

Mutaqin, B.K., D. S. Tasripin, L. Adriani, and U. H. Tanuwiria. 2019. effect of the addition of ca-pufa complexes to complete rations on fermentability and digestibility. Pakistan J. of Nutrition. 18:519-523.

Noorhadi dan Sudadi. 2003. Kajian pemberian air dan mulsa tergadap ikim makro pada tanaman cabai di tanah entisol. J. Ilmu Tanah dan Lingkungan. 4:41-49.

Panalosa. D., Oktafri dan M.Z. Kadir. 2015. Respon pertumbuhan dan produksi dua varietas tanaman kedelai (Glycine max L. Merrill) terhadap penipisan air tanah tersedia. J. Teknik Pertanian Lampung. 4:99-108.

Pangestu, E., T. Toharmat, dan U.H. Tanuwiria. 2003. Nilai nutrisi ransum berbasis limbah industri pertanian pada sapi perah laktasi. J. Indon. Trop. Anim. Agric. 28:166-171.

Prajnanta, F. 2004. Pemeliharaan Tanaman Budidaya Secara Intensif dan Kiat Sukses Beragribisnis. Penebar Swadaya. Bogor. 163 hlm.

Purwono dan P. Hanny. 2011. Budidaya 8 Jenis Tanaman Pangan Unggul. Penebar Swadaya. Jakarta.

Rochana, A., N.P. Indriani, B. Ayuningsih, I. Hernaman, T. Dhalika, D. Rahmat and S. Suryanah. 2016. Feed forage and nutrition value at altitudes during the dry season in West Java. Animal Production. 18:85-93.

Santosa, U., U.H. Tanuwiria, A. Yulianti, dan U. Suryadi. 2012. Pemanfaatan kromium organik limbah penyamakan kulit untuk mengurangi stres transportasi. J. Ilmu Ternak dan Veteriner. 17:132-141

Savitri, M.V., H.Sudarwati dan Hermanto. 2012. Pengaruh umur pemotongan 
terhadap produktivitas gamal (Gliricidia sepium). J. Ilmu-Ilmu Peternakan. 23:25-35

Setyowati, N. dan N.W.Utami. 2013. Pengaruh jarak tanam terhadap pertumbuhan dan produksi tiga aksesi jagung pulut lokal. J. Agrotropika 8:17.

Sirappa, M. P. 2003. Prospek pengembangan sorghum di Indonesia sebagai komoditas alternatif untuk pangan, pakan dan industri. J. Litbang Pertanian. 22:133-140.

Subandi, I. M. 1990. Penelitian dan Teknologi Peningkatan Produksi Jagung di Indonesia. Balitbangtan. Departemen Pertanian. Jakarta.

Subekti, N.A., Syarifuddin, R. Efendi, dan S. Sunarti. 2007. Morfologi Tanaman dan Fase Pertumbuhan Jagung dalam Buku Jagung, Teknik Produksi dan Pengembangan. Balai Penelitian Tanaman Serealia. Maros.

Susilawati, I., N.P. Indriani, L. Khairani, and U.H. Tanuwiria. 2019. Increase nutritional content and in vitro digestibility of forage legumes by adding molybdenum with foliar spray methods. Legume Research: An International J. 42:35-41.

Syafrudin dan T. Miranda. 2015. Vigor benih beberapa varietas jagung pada media tanam tercemar hidrokarbon. J. Floratek. 10:18-25.

Tanuwiria, U.H. 2004. Efek suplementasi Zn$\mathrm{Cu}$ proteinat dalam ransum terhadap fermentabilitas dan kecernaan in vitro. J. Ilmu Ternak. 4:7-12.

Tanuwiria, U.H. 2007a. Proteksi protein tepung ikan oleh berbagai sumber tannin dan pengaruhnya terhadap fermentabilitas dan kecernaannya (in vitro). J. Agroland. 14:56-60.

Tanuwiria, U.H., 2007b. Efek suplementasi kompleks mineral-minyak dan mineralorganik dalam ransum terhadap kecernaan ransum, populasi mikroba rumen dan performa produksi domba jantan. Prosiding Seminar Nasional dan
Kongres Asosiasi Ahli Nutrisi. AINI. 1:23-27.

Tanuwiria, U.H., A. Mushawwir, dan A.A. Yulianti. 2007. Potensi pakan serat dan daya dukungnya terhadap populasi ternak ruminansia di wilayah kabupaten Garut. J. Ilmu Ternak. 7:1116.

Van Soest, P. J. 1967. Development of a comprehensive system of feed analysis and its aplication to forage. J. Anim. Sci. 26:119-128. 